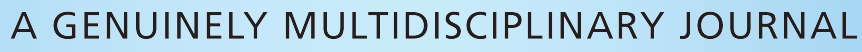 CHEMPLUSCHEM
}

CENTERING ON CHEMISTRY

\section{Accepted Article}

Title: Palladium Nanoparticles on a Creatine-Modified Bentonite Support: An Efficient and Sustainable Catalyst for Nitroarene Reduction

Authors: Carmen Nájera, Mohammad Gholinejad, Zahra Rasouli, and Jose M Sansano

This manuscript has been accepted after peer review and appears as an Accepted Article online prior to editing, proofing, and formal publication of the final Version of Record (VoR). This work is currently citable by using the Digital Object Identifier (DOI) given below. The VoR will be published online in Early View as soon as possible and may be different to this Accepted Article as a result of editing. Readers should obtain the VoR from the journal website shown below when it is published to ensure accuracy of information. The authors are responsible for the content of this Accepted Article.

To be cited as: ChemPlusChem 10.1002/cplu.201900377

Link to VoR: http://dx.doi.org/10.1002/cplu.201900377

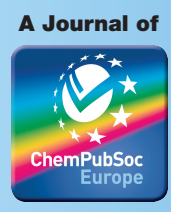




\title{
Palladium Nanoparticles on a Creatine-Modified Bentonite Support: An Efficient and Sustainable Catalyst for Nitroarene
} Reduction

\author{
Mohammad Gholinejad, ${ }^{*}[a, b]$ Zahra Rasouli, ${ }^{[a]}$ Carmen Najera ${ }^{*}[c]$ José M. Sansano ${ }^{[c]}$
}

Dedication ((optional))

\begin{abstract}
Creatine as the nitrogen-rich, green and cheap compound is used for modification of natural bentonite and the resulting material employed for stabilization of Pd nanoparticles having an average diameter of $3 \mathrm{~nm}$. This new material bento-crt@Pd characterized using different techniques such as X-ray diffraction (XRD), Fouriertransform infrared spectroscopy (FTIR), solid state UV-vis, scanning electron microscopy (SEM), transmission electron microscopy (TEM), $\mathrm{X}$-ray photoelectron spectroscopy (XPS), thermogravimetric analysis (TGA), and energy-dispersive X-ray spectroscopy (EDX). This green catalyst promotes the efficient reduction of aromatic nitro compounds in aqueous media. Using this catalyst, nitroarenes having electron donating as well as electron withdrawing groups were reduced efficiently to corresponding amines at room temperature. The catalyst can be recycled for seven times and reused catalyst was characterized by TEM and XPS.
\end{abstract}

\section{Introduction}

Aromatic amines are important class of molecules present in pharmaceutical drugs, natural products, and agrochemicals. In addition, anilines are important starting material for the synthesis of a wide variety of organic molecules. ${ }^{[1]}$ One of the common methods for synthesizing amines is through the reduction of corresponding nitro compounds. Traditional methods such as Bechamp reduction suffer from several drawbacks such as low efficiency, costly steam distillation and production of a large number of waste. ${ }^{[2]}$ In recent years, transition metal catalyzed reduction of nitro compounds using various reducing agents is a straightforward protocol for the production of amines. ${ }^{[3]}$ Amongst the different transition metals, palladium is very efficient for the

[a] Mohammad Gholinejad, Zahra Rasouli

Department of Chemistry, Institute for Advanced Studies in

Basic Sciences (IASBS), P. O. Box 45195-1159, Gavazang,

Zanjan 45137-66731, Iran.

E-mail: gholinejad@iasbs.ac.ir

[b] Mohammad Gholinejad,

Research Center for Basic Sciences \& Modern Technologies (RBST), Institute for Advanced Studies in Basic Sciences (IASBS), Zanjan 45137-66731, Iran.

[c] Carmen Nájera, José M. Sansano

Centro de Innovación en Química Avanzada (ORFEO-CINQA).

Universidad de Alicante, Apdo. 99, E-03080-Alicante, Spain.

Email: cnajera@ua.es

Supporting information for this article is given via a link at the end of the document. selective reduction of nitro compounds to amines. There are a considerable number of homogeneous and heterogeneous palladium catalysts which have been reported for performing nitroarenes reduction. ${ }^{[4]}$ However, due to high price and toxicity of palladium and probability of product contamination with $\mathrm{Pd}$ which has $\leq 5 \mathrm{ppm}$ allowance, there is a growing demand for using high TON and recyclable catalysts. ${ }^{[5]}$ Along with this line for green chemistry standpoints, the use of naturally occurring compounds and materials are highly desirable for design and synthesis of heterogeneous catalysts. ${ }^{6]}$ Clay minerals having different properties such as cheap price, high surface area, mechanical and thermal stability, and ion exchange ability are among the promising supports for the preparation of heterogeneous catalysts. Bentonite is one of the wide families of clay materials which is the result of the devitrification and chemical variation of glassy volcanic ash or tuff. Bentonite is of great industrial importance for different applications such as binder in tablet manufacturing and in diarrhea medications, as filler in pharmaceuticals, wastewater purification, removal of impurities in oils, animal feed supplement, suspension agent in varnishes etc. ${ }^{[7]}$ Moreover, one of the important aspects of bentonite, include its application in catalytic process. Along with this line, chemically-modified bentonite supported transition metals are employed in different organic reactions. For achieving desired properties, different ligands are used for modification of this solid support and its following application for stabilization of transition metals. ${ }^{\left[{ }^{[3]}\right.}$

Creatine is an amino acid containing a guanidine unit, which it is not a proteinogenic amino acid. Creatine can be attained in the food we eat (typically meat and fish) or formed endogenously in the body from the amino acids glycine, arginine, and methionine. ${ }^{[9]}$ In this work, we describe the use of creatine as a ligand for the modification of bentonite as green and naturally available solid and the resulting material is employed for the stabilization of $\mathrm{Pd}$ nanoparticles and applied as a heterogeneous catalyst in the reduction of nitroarenes.

\section{Results and Discussion}

The catalyst preparation steps are summarized in Scheme 1. Briefly, natural bentonite was treated with (3-chloropropyl) triethoxysilanein toluene under reflux condition to afford chloro functionalized bentonite, which was allowed to react with creatine in the presence of triethylamine in xylene at $130{ }^{\circ} \mathrm{C}$ affording bentonite-creatine (bento-crt). Finally, Pd NPs supported on creatine modified bentonite were easily obtained by dissolving 


\section{WILEY-VCH}

\section{FULL PAPER}

and sonicating $\mathrm{PdCl}_{2}$ in water followed by treating with bento-crt. Using atomic absorption spectroscopy (AAS), the loading of $\mathrm{Pd}$ was found to be $0.08 \mathrm{mmol} / \mathrm{g}$. This new material is referred to as bento-crt@Pd throughout the text of this article.

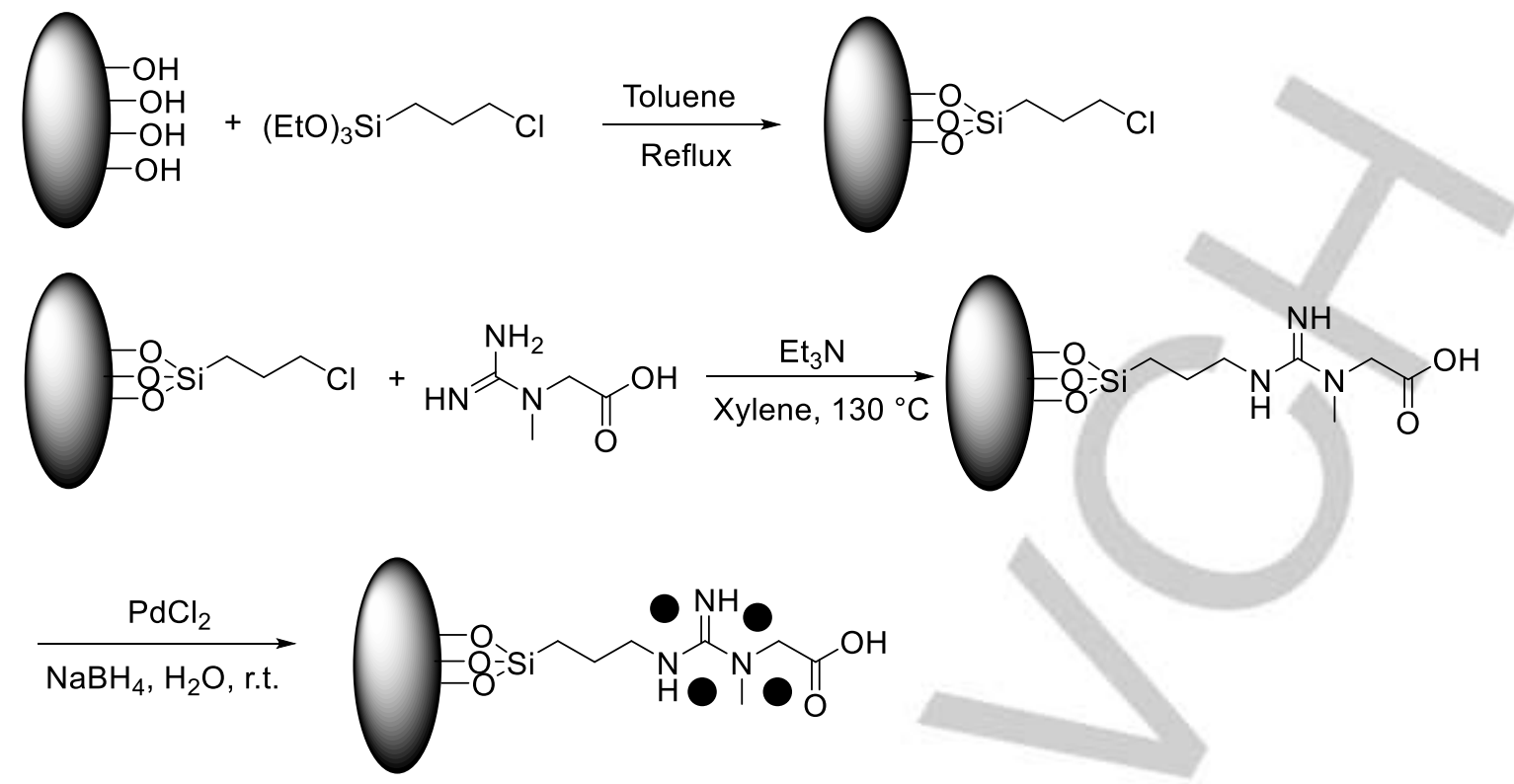

Scheme 1. The synthetic route toward the bento-crt@Pd.

In order to confirm the successful attachment of creatine to bentonite, structure of creatine, bentonite, and bento-crt were studied by Fourier-transform infrared spectroscopy (FT-IR). Results indicated sharp absorption peak at $1696 \mathrm{~cm}^{-1}$ related to $\mathrm{C}-\mathrm{O}$ stretching vibrations of carboxylic acid in creatine as well as in bento-crt. In addition, an absorption peak related to C-N stretching vibrations of guanidine at $1615 \mathrm{~cm}^{-1}$ and peak related to $\mathrm{NH}$ stretching vibrations centered at $3339 \mathrm{~cm}^{-1}$ were observable in both creatine and bento-crt, indicating successful grafting of creatine. Also, an absorption peak at $2786 \mathrm{~cm}^{-1}$ is related to vibrations of the $\mathrm{C}-\mathrm{H}$ bonds of the methyl group (Figure 1). ${ }^{[10]}$

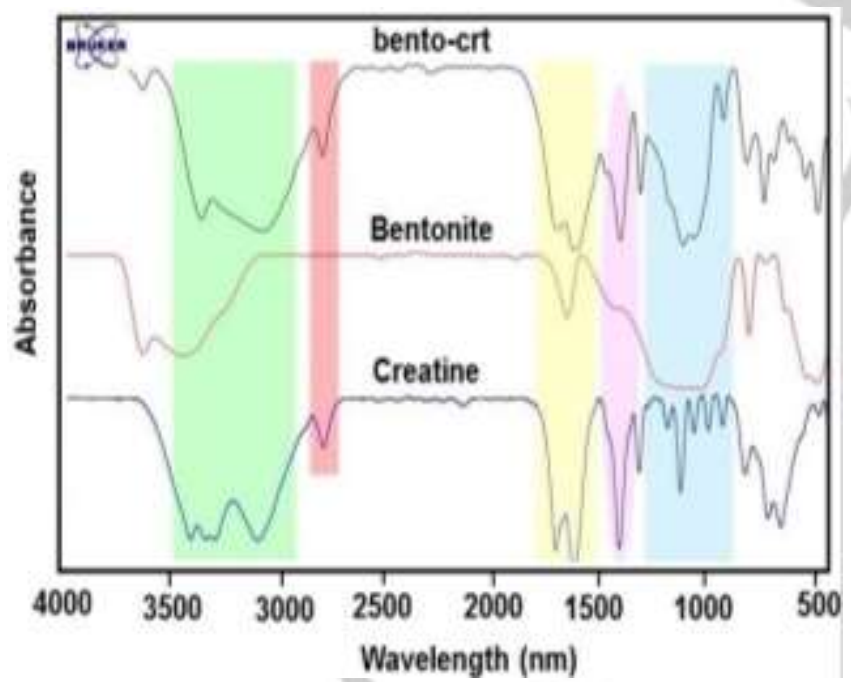

Figure 1. FT-IR spectra of creatine, bentonite and bento-crt.
Thermogravimetric analyses (TGA) of bentonite@Cl and bento-crt were studied between 25 and $800{ }^{\circ} \mathrm{C}$. TGA measurements for bento-crt showed prominent increasing of weight loss between $150-800^{\circ} \mathrm{C}$ due to the addition of creatine as an organic group (Figure 2).

The BET surface area decreased in bentonite@Cl (238.627 $\left.\mathrm{m}^{2} / \mathrm{g}\right)$ compared with bento-crt $\left(24.032 \mathrm{~m}^{2} / \mathrm{g}\right)$ which may be attributed to the possibility that the pores of bentonite@Cl covered by creatine.

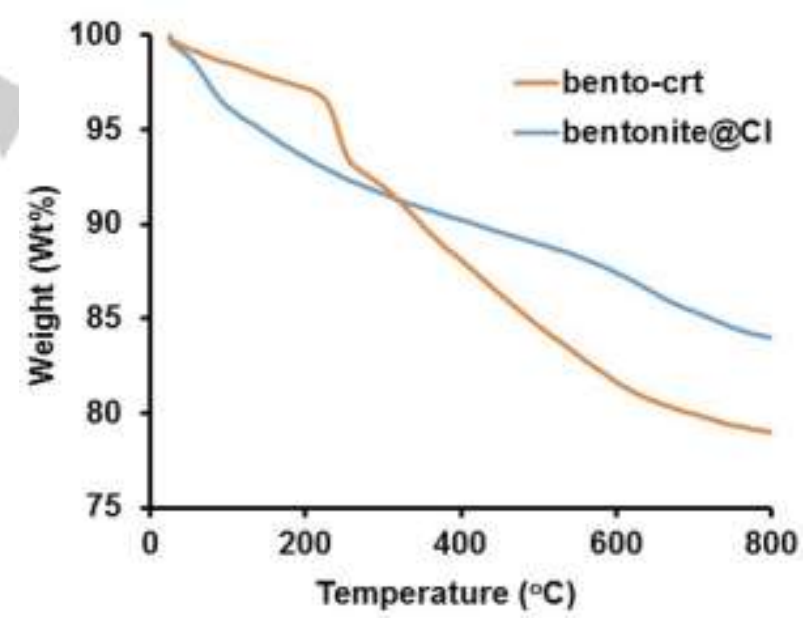

Figure 2. Thermogravimetric diagrams of bentonite@Cl, bento-crt.

Solid state UV-vis spectra of palladium chloride and bentocrt@pd were also studied (Fig. 1, ESI). The reduction of Pd(II) to 


\section{WILEY-VCH}

\section{FULL PAPER}

$\mathrm{Pd}(0)$ in bento-crt@Pd was confirmed by the disappearance of a peak at $280 \mathrm{~nm}$ corresponding to $\mathrm{Pd}(\mathrm{II})$ species. $^{[11]}$

The corresponding scanning electron microscope (SEM) images of bento-crt@Pd at different magnifications showed the presence of $\mathrm{Pd}$ nanoparticles (bright dots) stabilized on clay layers (Fig. 2, ESI). Also, transmission electron microscope (TEM) images of bento-crt@Pd in different magnifications indicate incorporation of uniformly dispersed Pd NPs with the calculated average size of $3.1 \mathrm{~nm}$ (Figure 3).

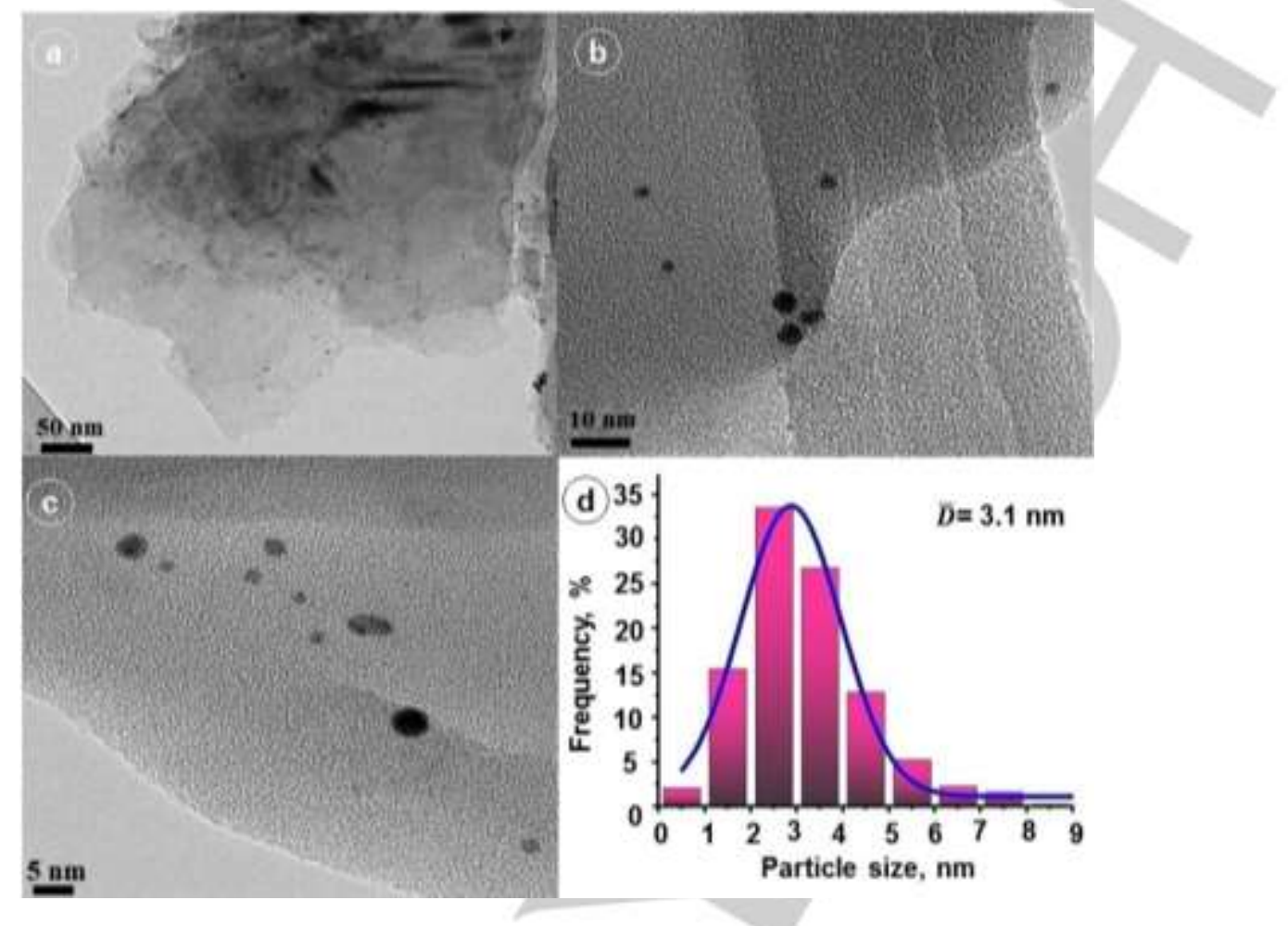

Figure 3. TEM images of bento-crt@Pd in different magnification (a-c). The solid curve is Gaussian fit to the data (d).

X-ray diffraction (XRD) analysis of the bento-crt@Pd showed the Bragg's reflections related to bentonite ${ }^{[12]}$ at $2 \theta=20,22,27.9$, $35.4,62$ and also the presence of $\operatorname{Pd}(0)$ based on the Bragg's reflections related to palladium ${ }^{[13]}$ that appeared at $2 \theta=40.2,46.7$ and 68.2 (Figure 4).

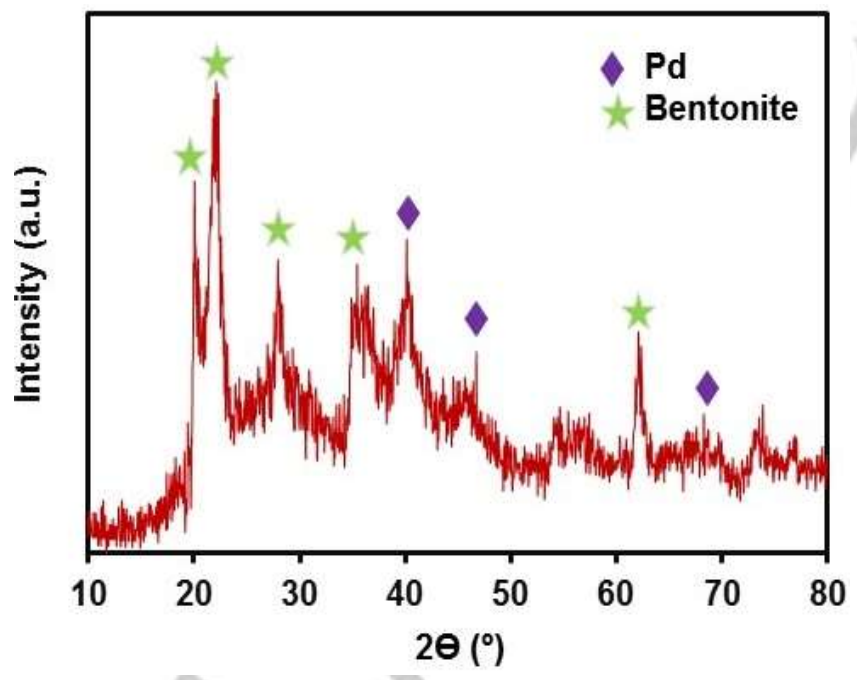

Figure 4. XRD pattern of bento-crt@Pd.
Energy dispersive X-Ray spectroscopy (EDS) obtained from SEM analysis confirmed the presence of bentonite elements as well as $\mathrm{N}$ and $\mathrm{Pd}$ (Table 1 in ESI) in the structure of the bentocrt@Pd (Figure 5).

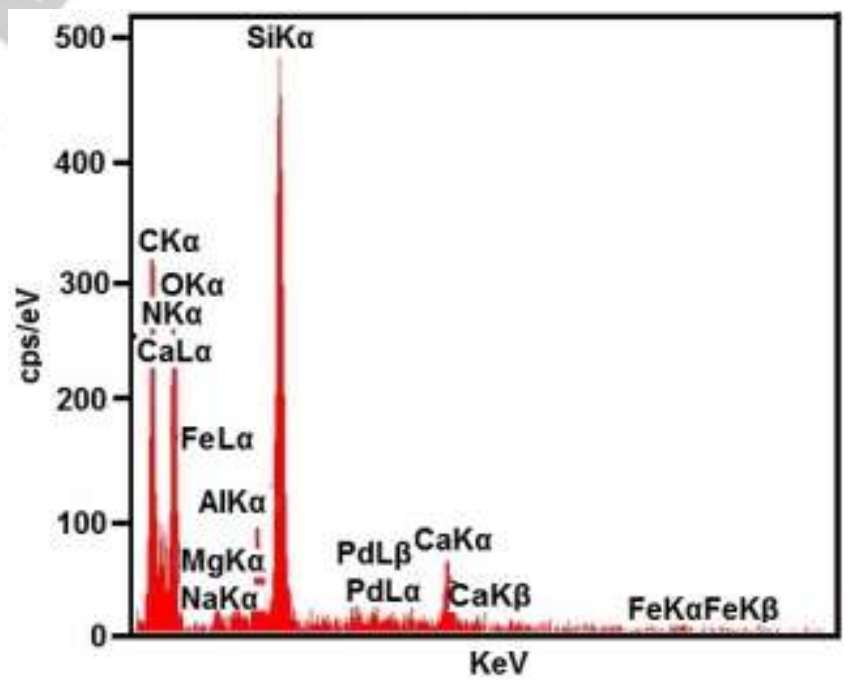

Figure 5. EDS spectrum of bento-crt@Pd. 


\section{FULL PAPER}

X-ray photoelectron spectroscopy (XPS) of bentonite@Cl in $\mathrm{Mg}, \mathrm{Na}, \mathrm{Ca}, \mathrm{Al}, \mathrm{Si}, \mathrm{Cl}, \mathrm{C}$, and O were studied. The XPS spectrum of $\mathrm{Mg}$ 1s showed a peak at $1302 \mathrm{eV}$ confirming the presence of $\mathrm{Mg}(\mathrm{II})$ in the structure of bentonite (Figure 6a). ${ }^{[14]}$ The binding energy observed for $\mathrm{Na} 1 \mathrm{~s}$ is $1071.9 \mathrm{eV}$, which is characteristic of $\mathrm{Na}(\mathrm{l})$ oxidation state (Figure 6b). ${ }^{[15]}$ Furthermore, XPS spectrum in the $\mathrm{Ca} 2 \mathrm{p}$ region confirm the presence of $\mathrm{Ca}(\mathrm{II})$ with showing a doublet peak located at 347 and $350.5 \mathrm{eV}$ (Figure 6c). ${ }^{[16]}$ Presence of $\mathrm{Al}(\mathrm{III})$ in the structure was confirmed with appearing two peaks at 73.6 and $74.2 \mathrm{eV}$ related to $\mathrm{Al} 2 \mathrm{p}$ (Figure $6 \mathrm{~d}$ ). ${ }^{[17]}$ The binding energy of Si $2 p$ appears at 101.9 and $102.7 \mathrm{eV}$, which are related to the Si-O bond (Figure 6e). ${ }^{[17 b]}$ XPS spectrum in $\mathrm{Cl} 2 p$ region show two peaks center at 200.4 and $201.78 \mathrm{eV}$ corresponding to $\mathrm{Cl} 2 \mathrm{p}_{3 / 2}$ and $\mathrm{Cl} 2 \mathrm{p}_{1 / 2}$ (Figure 6f). ${ }^{[18]}$ In addition, peaks located at 284.7, 287.08 and $287.7 \mathrm{eV}$ were related to $\mathrm{C} 1 \mathrm{~s}$ orbital in $\mathrm{C}-\mathrm{C} / \mathrm{C}-\mathrm{H}, \mathrm{C}-\mathrm{O} / \mathrm{C}-\mathrm{Cl}$ and $\mathrm{O}-\mathrm{C}-\mathrm{O}$ forms, respectively (Figure $6 \mathrm{~g}) .{ }^{[19]}$ XPS spectrum in $\mathrm{O} 1 \mathrm{~s}$ region showed three peaks between 529.0-533.0 related to oxygen of metal oxides in clay structure (Figure 6h). ${ }^{20]}$
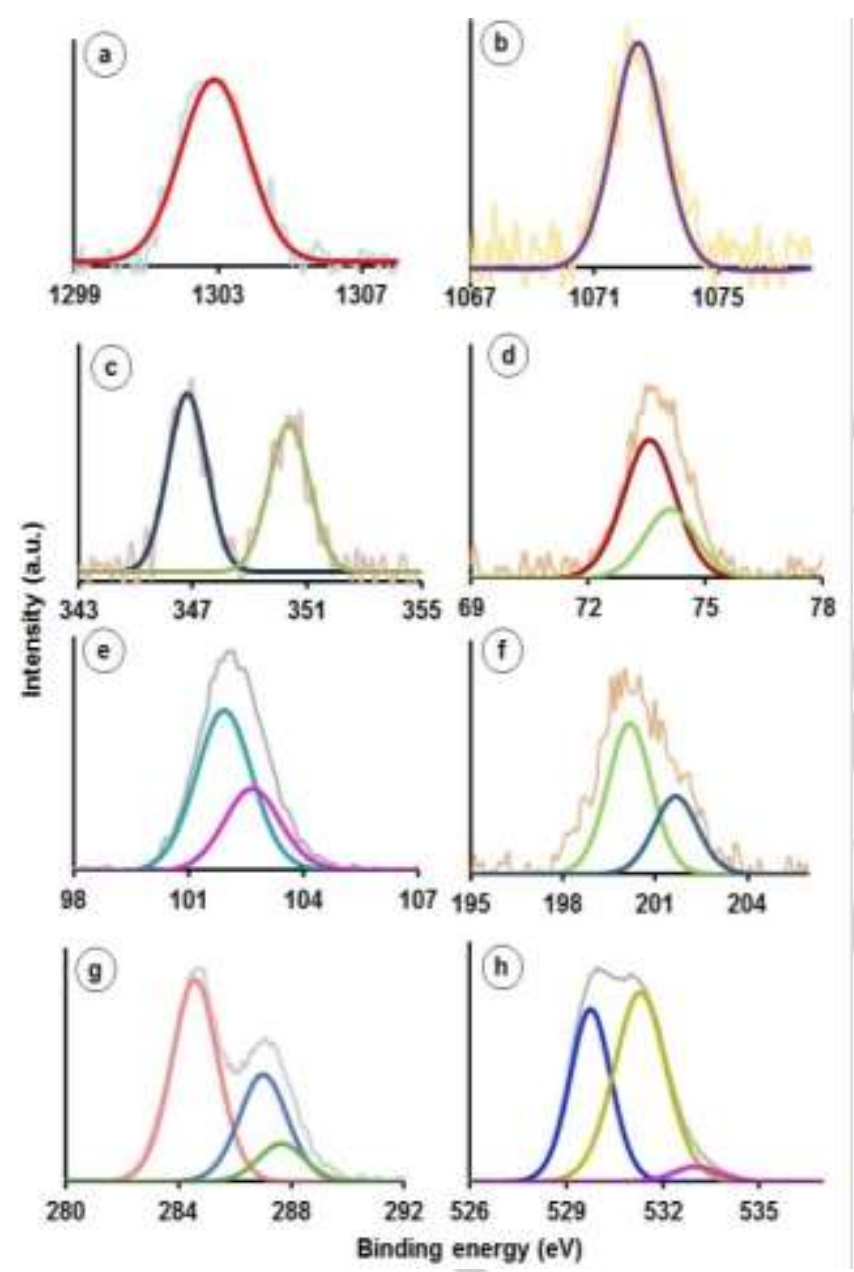

Figure 6. XPS spectrum of bentonite@Cl in a) Mg 1s, b) Na 1s, c) Ca 2p, d) Al $2 \mathrm{p}, \mathrm{e}) \mathrm{Si} 2 \mathrm{p}, \mathrm{f}) \mathrm{Cl} 2 \mathrm{p}, \mathrm{g}) \mathrm{C}$ 1s, and h) O1s regions.

In order to confirm the addition of creatine, XPS spectrum of a region of $\mathrm{N} 1 \mathrm{~s}$ was studied, and results showed an intense peak at $400 \mathrm{eV}$ related to the nitrogen of creatine (Figure $7 \mathrm{a}) .{ }^{[21]}$ The
XPS spectrum in the $\mathrm{Pd} 3 \mathrm{~d}$ region showed the presence of two intense doublets at 335.6 and $340.9 \mathrm{eV}$ related to $\mathrm{Pd}(0)$ and peaks at 337.7 and $342 \mathrm{eV}$ related to $\mathrm{Pd}(\mathrm{II})$ corresponding to $\mathrm{Pd}$ $3 d_{5 / 2}$ and $P d 3 d_{3 / 2}$, respectively (Figure $7 b$ ). ${ }^{[22]}$

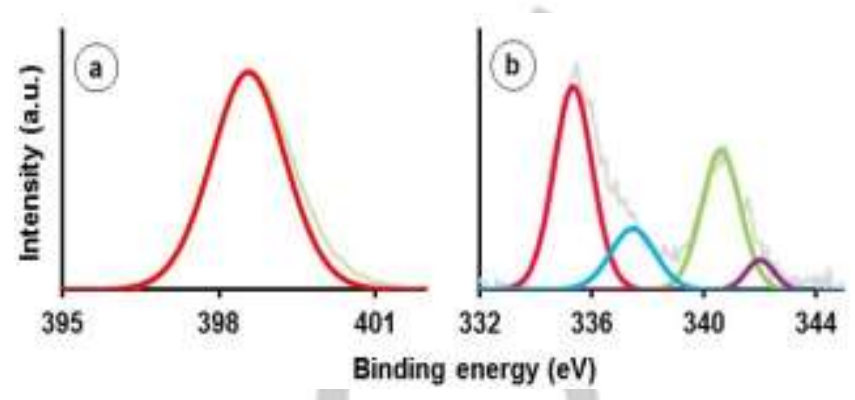

Figure 7. XPS spectrum of bento-crt@Pd in a) N 1s, b) Pd 3d.

Catalytic activity of bento-crt@Pd was evaluated in reduction of nitroarenes. In order to find optimized reaction conditions, reduction of 1-chloro-4-nitrobenzene as a model reaction was selected and effect of different factors such as catalyst amount, solvent, time and reducing agent were studied (Table 1). Using $0.04 \mathrm{~mol} \%$ of $\mathrm{Pd}$ in different solvents such as $\mathrm{H}_{2} \mathrm{O}, \mathrm{EtOH}, \mathrm{THF}$, DMF, DMSO, 1,4-dioxane, PEG200, isopropanol, and acetone gave poor to low yields in $30 \mathrm{~min}$ (Table 1, entries 1-9). However, using an equal mixture of $\mathrm{EtOH}-\mathrm{H}_{2} \mathrm{O}$ afford $25 \% \mathrm{GC}$ yield for the desired 4-chloroaniline product (Table 1, entry 10). By increasing reaction time to 45 and $60 \mathrm{~min}, 33$ and $71 \%$ yields were obtained, respectively (Table 1 , entries $11-12$ ). Then, the catalyst amount was increased to 0.06 and $0.1 \mathrm{~mol} \%$ and the progress of the reaction at different times were studied (Table 1, entries 13-15). Results indicated that using $0.1 \mathrm{~mol} \%$ catalyst in $30 \mathrm{~min}$ afforded quantitative yield for the reaction (Table 1, entry 15). With decreasing reaction time to 20 and $15 \mathrm{~min}$, yields dropped to 69 and $50 \%$ respectively (Table 1 , entries $16-17$ ). Therefore, we selected $0.1 \mathrm{~mol} \%$ of $\mathrm{Pd}$ loading, $\mathrm{EtOH}-\mathrm{H}_{2} \mathrm{O}(1: 1)$ as solvent, $\mathrm{NaBH}_{4}$ as a reducing agent at room temperature during 30 min as the best-optimized reaction conditions (Table 1 , entry 15 ). It is worth mentioning that in the absence of catalyst or $\mathrm{NaBH}_{4}$ the reaction did not proceed (Table 1, entries 18 and 19). Also, it should be noted that using other reducing agents such as formic acid, ammonium formate, hydrazine, glycerol, and isopropyl alcohol gave lower yields than $\mathrm{NaBH}_{4}$ (Table 2 in ESI).

Table 1. Optimization of the reaction conditions for the reduction of 1-chloro-4 nitrobenzene ${ }^{[a]}$.

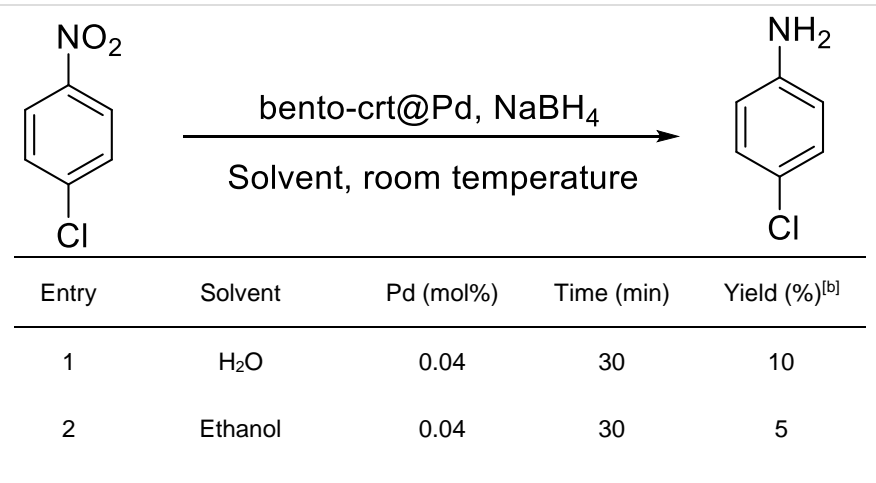


WILEY-VCH

FULL PAPER

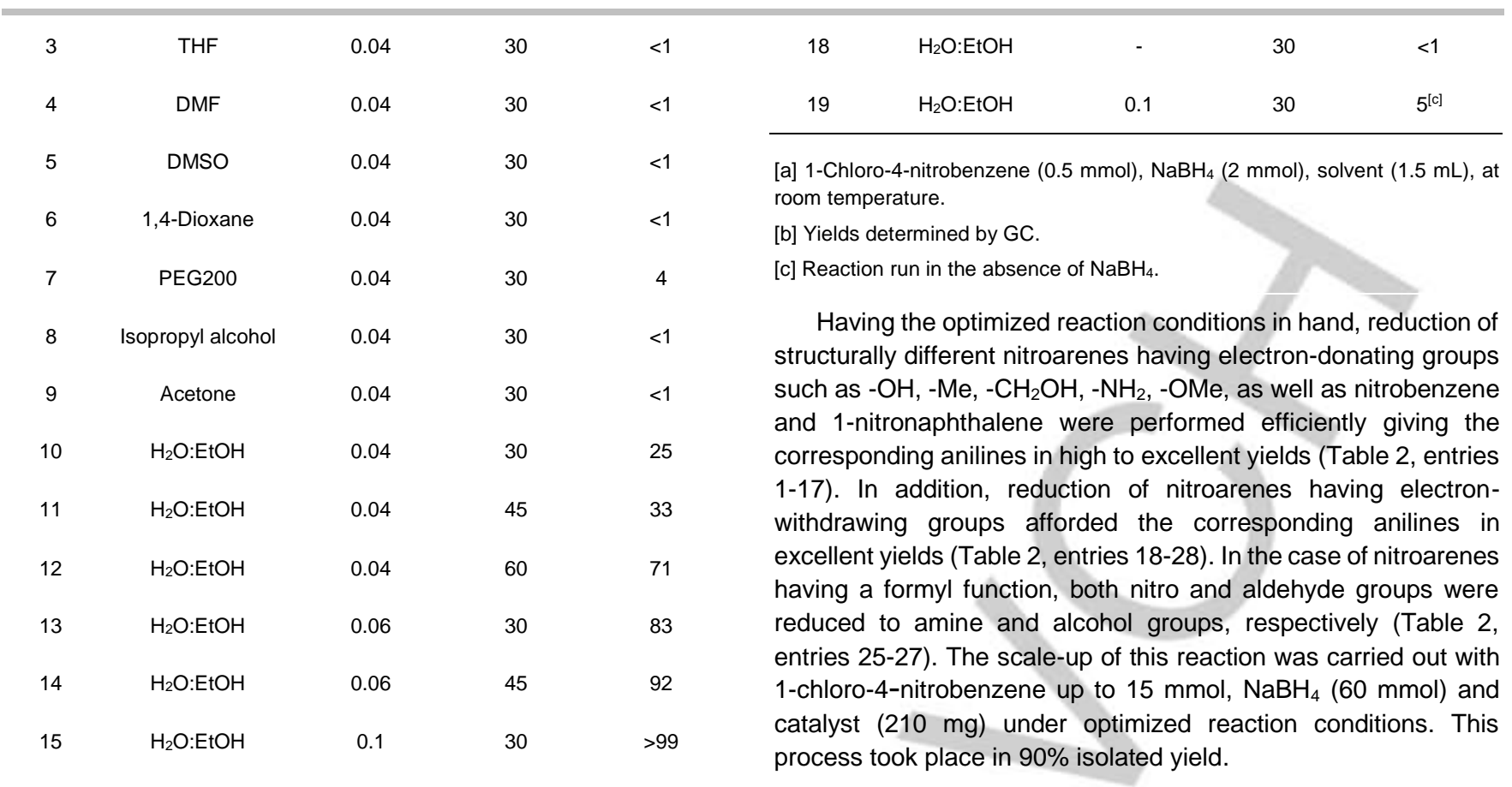

$\begin{array}{lllll}16 & \mathrm{H}_{2} \mathrm{O}: \mathrm{EtOH} & 0.1 & 20 & 69 \\ 17 & \mathrm{H}_{2} \mathrm{O}: \mathrm{EtOH} & 0.1 & 15 & 50\end{array}$

Table 2. Reduction of structurally different nitroarenes using bento-crt@Pd ${ }^{[a]}$.

Entry

2<smiles>O=[N+]([O-])c1cccc2ccccc12</smiles><smiles>[O][N+](=O)[O-]</smiles>

3<smiles>Cc1ccc([N+](=O)[O-])cc1</smiles>

$\mathrm{NO}_{2}$
4<smiles>Cc1ccccc1C</smiles>

5<smiles>O=[N+]([O-])c1ccccc1CO</smiles>

60<smiles>Nc1cccc2ccccc12</smiles>

30<smiles>Cc1ccc(N)cc1</smiles>

30<smiles>Cc1ccccc1N</smiles>

30<smiles>Nc1ccccc1CO</smiles>

90

93

85

90 
WILEY-VCH

FULL PAPER<smiles>O=[N+]([O-])c1cccc(CO)c1</smiles><smiles>CCCc1ccc(CO)cc1</smiles>

8<smiles>O=[N+]([O-])c1cccc(O)c1</smiles>

9<smiles>O=[N+]([O-])c1ccccc1O</smiles>

10<smiles>O=[N+]([O-])c1ccc(O)cc1</smiles>

11<smiles>Nc1ccccc1[N+](=O)[O-]</smiles>

2<smiles>Nc1cccc([N+](=O)[O-])c1</smiles>

13<smiles>Nc1ccc([N+](=O)[O-])cc1</smiles>

14<smiles>COc1ccccc1[N+](=O)[O-]</smiles>
$\mathrm{NO}_{2}$

15<smiles>COc1cccc(N(C)O)c1</smiles>

$\mathrm{OMe}$<smiles>COc1ccc([N+](=O)[O-])cc1</smiles>

30<smiles>Nc1cccc(CO)c1</smiles>

93<smiles>Nc1ccc(CO)cc1</smiles>

30<smiles>Nc1cccc(O)c1</smiles>

45<smiles>Nc1ccccc1O</smiles>

30<smiles>Nc1ccc(O)cc1</smiles>

$\mathrm{NH}_{2}$<smiles>Nc1ccccc1N</smiles>

30<smiles>Nc1cccc(N)c1</smiles><smiles>Nc1ccc(N)cc1</smiles>

$\mathrm{NH}_{2}$

60<smiles>COc1ccccc1C</smiles><smiles>COc1cccc(N)c1</smiles><smiles>COc1ccc(N)cc1</smiles>

84

$99^{[c]}$

$88^{[c]}$

$95^{[c]}$

88

90

$96^{[c}$

$92^{[\mathrm{c}]}$

$99^{[c]}$ 
WILEY-VCH

FULL PAPER

17<smiles>Nc1ccc([N+](=O)[O-])cc1N</smiles>

18<smiles>O=[N+]([O-])c1ccccc1[N+](=O)[O-]</smiles>

9<smiles>O=[N+]([O-])c1ccc([N+](=O)[O-])cc1</smiles><smiles>O=[N+]([O-])c1ccc(Br)cc1</smiles>

21

20<smiles>[O+][Os]</smiles><smiles>Cc1ccc(Cl)cc1</smiles>

$\mathrm{NO}_{2}$

22<smiles>Cc1ccc(F)cc1</smiles>

$F$

23<smiles>O=[N+]([O-])c1ccc(Cl)c([N+](=O)[O-])c1</smiles>

$\mathrm{NO}_{2}$

24<smiles>Nc1cc(Cl)ccc1[N+](=O)[O-]</smiles>

$\mathrm{NH}_{2}$
30<smiles>Nc1ccc(N)c(N)c1</smiles>

60<smiles>Nc1ccc(N)cc1</smiles><smiles>Nc1ccc(Br)cc1</smiles><smiles>[15NH2]</smiles>

30<smiles>Nc1ccc(Cl)cc1</smiles><smiles>Nc1ccc(F)cc1</smiles>

$\mathrm{NH}_{2}$<smiles>Cc1ccc(Cl)c(N)c1</smiles><smiles>N</smiles><smiles>Nc1ccc(Cl)cc1N</smiles>

30

30<smiles>Nc1cccc(CO)c1</smiles>

90 95

86 $95^{[c]}$

$>99^{[c]}$

$90^{[c]}$

92

93

$96^{[c]}$ 
26<smiles>O=Cc1ccc([N+](=O)[O-])cc1</smiles>

27<smiles>O=Cc1ccccc1[N+](=O)[O-]</smiles>

30<smiles>Nc1ccc(CO)cc1</smiles>

30<smiles>Nc1ccccc1CO</smiles>

$98^{[c]}$

$94^{[c]}$

[a] Nitroarene (0.5 mmol), bento-crt@Pd (7 mg, 0.1 mol\%), $\mathrm{NaBH}_{4}(2 \mathrm{mmol}), \mathrm{H}_{2} \mathrm{O}: \mathrm{EtOH}(1: 1,1.5 \mathrm{~mL})$, at room temperature.

[b] Isolated yield.

[c] Yield determined by GC.

In order to assess the recycling ability of this novel bentonite supported palladium catalyst, reduction of 1-chloro-4nitrobenzene under the optimized reaction conditions was studied. For this purpose, in each cycle the heterogeneous catalyst was easily separated using centrifugation, washed with ethanol and used directly for a subsequent round of the reaction. The catalyst was recyclable for at least seven consecutive times with small drops in its catalytic activity (Figure 8). Leaching study of Pd from the catalyst during three recycling steps indicated that very small amount of $\mathrm{Pd}(0.4-1.5 \%)$ was leached conforming important role of creatine in the stability of the catalyst (Table 3 ).

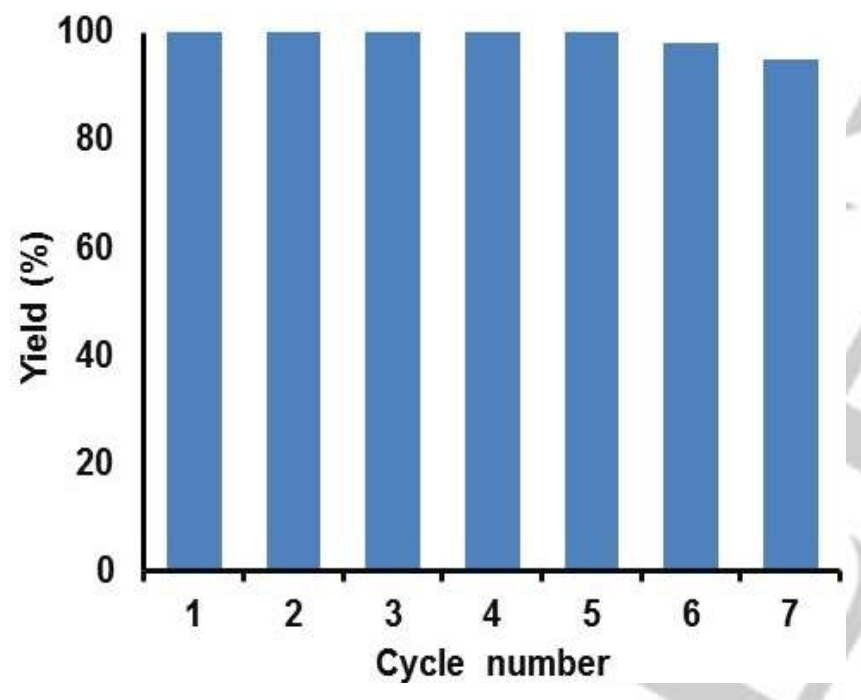

Figure 8. Recycling of the catalyst, bento-crt@Pd, for the reduction of 1chloro-4-nitrobenzene.

\begin{tabular}{ccc}
\hline 1 & First cycle & \\
2 & Second cycle & 0.4 \\
3 & Third cycle & 0.9 \\
\hline
\end{tabular}

[a] 1-Chloro-4-nitrobenzene (0.5 mmol), bento-crt@Pd (7 mg, 0.1 mol\%), $\mathrm{NaBH}_{4}(2 \mathrm{mmol})$, solvent $(1.5 \mathrm{~mL})$, at room temperature.

SEM images of the reused catalyst after the $7^{\text {th }}$ run exhibited the morphology and structure of the catalyst have been preserved during the reaction (Fig. 3, ESI). In addition, TEM images of reused catalyst showed preservation of structure and the presence of Pd NPs in very slightly aggregate form and bigger size than fresh catalyst (Figure 9). XPS study in $\mathrm{N}$ 1s region showed also structure preservation and a very similar pattern to fresh catalyst. However, in the case of $\mathrm{Pd} 3 \mathrm{~d}$ region showed that during the recycling of $\mathrm{Pd}(\mathrm{II})$ species all of them were reduced to $\operatorname{Pd}(0)$ (Figure 10).

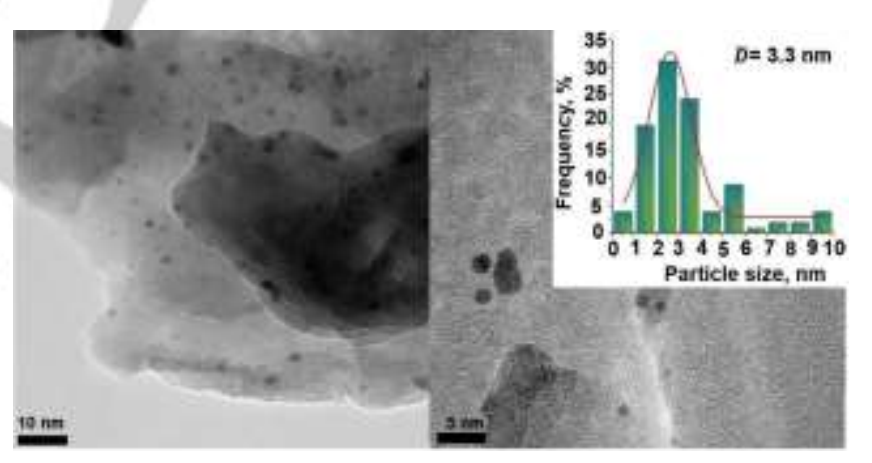

Figure 9.TEM images of reused catalyst bento-crt@Pd after 7 runs.

Table 3. Leaching of Pd from the catalyst in the reduction of 1-chloro-4nitrobenzene. ${ }^{[a]}$

\begin{tabular}{ccc} 
Eento-crt@Pd $(0.1 \mathrm{~mol} \%)$ \\
Entry & $\begin{array}{c}\text { Cycle } \\
\text { r.t. } 30 \mathrm{~min} .1: 1)\end{array}$ \\
\hline
\end{tabular}


WILEY-VCH

\section{FULLPAPER}

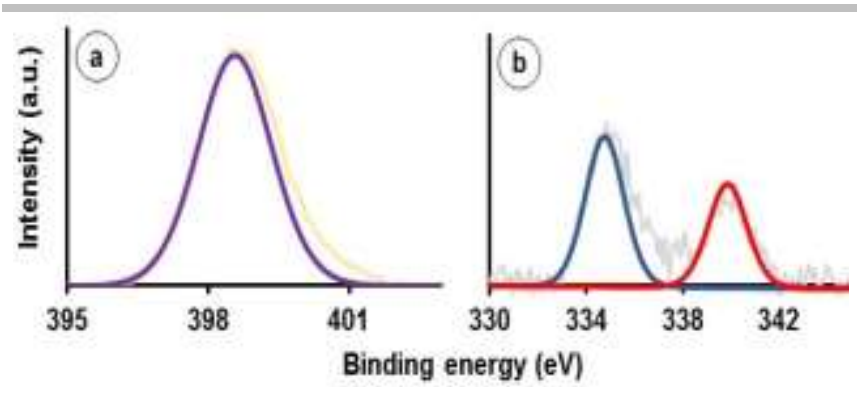

Figure 10. XPS images of reused catalyst bento-crt@Pd in N and Pd regions.

In order to show the effect of creatine in the stabilization of $\mathrm{Pd}$ NPs in the catalyst, we prepared bentonite supported Pd NPs in the absence of creatine via direct treating of bentonite with $\mathrm{PdCl}_{2}$ and $\mathrm{NaBH}_{4}$. TEM images of bentonite supported $\mathrm{Pd}$ indicated formation of uninform and almost aggregate Pd NPs (Fig. 4, ESI). Catalytic and recycling abilities of this material were examined in the reduction of 1-chloro-4-nitrobenzene. Results indicated using $0.1 \mathrm{~mol} \%$ of this catalyst, corresponding amine product was obtained in $90 \%$. However, in runs 2 and 3, yields decreased dramatically to 14 and $7 \%$ indicating leaching and deactivation of $\mathrm{Pd}$ during the recycling process (Figure 11).

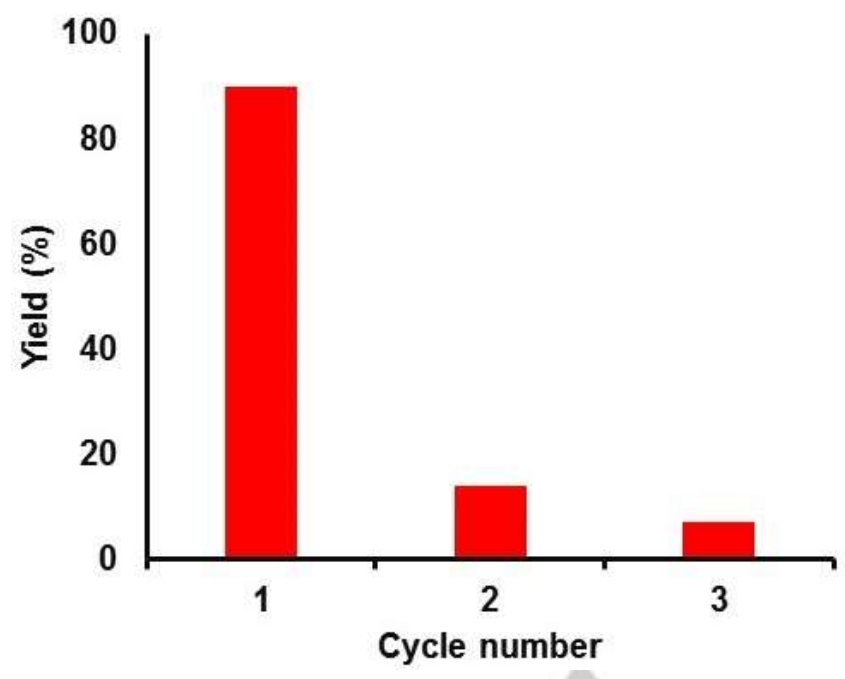

Figure 11. Recycling of the bentonite supported $\mathrm{Pd}$ for the reduction of 1-chloro-4-nitrobenzene.

\section{Conclusions}

In conclusion, we have prepared creatine modified bentonite supported Pd NPs, bento-crt@Pd. This new material has been applied as a sustainable catalyst in the reduction of aromatic nitro compounds. Using this $\mathrm{Pd}$ catalyst structurally different nitroarenes were selectively reduced in aqueous media, and corresponding amines were achieved in high to excellent yield at room temperature. This catalyst can be easily recovered by separation with a centrifuge and reused for at least seven cycles without noticeable detriment to its catalytic activity. The fresh and reused catalyst was characterized using different techniques.

\section{Experimental Section}

\section{General remarks}

All materials were purchased from Sigma-Aldrich, Across and Merck Millipore. Reactions were monitored by gas chromatography in a Varian CP-3800 apparatus. ${ }^{1} \mathrm{H}$ NMR spectra were recorded at $400 \mathrm{MHz}$ on a Bruker Avance HD apparatus in DMSO- $\mathrm{d}_{6}$. Chemical shifts are given on the $\delta$-scale in ppm, and residual solvent peaks were used as internal standards. X-ray photoelectron spectroscopy (XPS) analyses were performed using a K-Alpha spectrometer. XRD patterns were recorded using a Philips X'Pert Pro instrument. Fourier transform-infrared (FT-IR) studies of samples were performed using a FT-IR spectrophotometer Bruker vector 22, by preparing their $\mathrm{KBr}$ pellets from 400 to $4000 \mathrm{~cm}^{-1}$. The transmission electron microscopy (TEM) and scanning electron microscopy (SEM) mapping images were captured with EOL JEM-2010 and Hitachi S3000 N. The weight loss of samples was measured using a thermogravimeter NETZSCH STA 409 under an $\mathrm{O}_{2}$ flow rate of $20 \mathrm{Ml} \mathrm{min}^{-1}$ with a heating rate of $10^{\circ} \mathrm{C} \mathrm{min}-1$ from 30 to $800^{\circ} \mathrm{C}$. Digital images of the samples were acquired with Hitachi S4160 FE-SEM apparatus operating at $20 \mathrm{kV}$. Energy dispersive X-ray analysis (EDX) results were obtained using Carl Zeiss Sigma instrument. BET surface area of samples were measured using QUANTACHROME Poremaster $60 \mathrm{GT}$ instrument.

\section{Procedure for the preparation of bento-crt}

In $50 \mathrm{~mL}$ flask, bentonite $(2.6 \mathrm{~g})$ was sonicated in dry toluene $(30 \mathrm{~mL})$ for $15 \mathrm{~min}$. Then, (3-chloropropyl)triethoxysilane $(10 \mathrm{mmol}, 2.4 \mathrm{~mL})$ was added and the mixture was refluxed at $110{ }^{\circ} \mathrm{C}$ for $24 \mathrm{~h}$ under argon atmosphere. Afterward, the solid was separated by centrifugation, washed with ethyl acetate $(3 \times 10 \mathrm{~mL})$ and dried in an oven at $60^{\circ} \mathrm{C}$ affording bentonite@Cl. In the next step, in a $25 \mathrm{~mL}$ flask, bentonite@Cl $(2.5 \mathrm{~g})$ was sonicated in xylene $(30 \mathrm{~mL})$ for 15 minutes, and creatine $(10 \mathrm{mmol}, 1.3 \mathrm{~g})$ and $\mathrm{Et}_{3} \mathrm{~N}(20 \mathrm{mmol}, 2.8 \mathrm{~mL}$ ) were added. The reaction mixture was stirred at $130{ }^{\circ} \mathrm{C}$ for $24 \mathrm{~h}$. Then, the reaction mixture was subjected to centrifugation and for ensuring removing of unreacted creatine, resulting solid (bento-crt) was washed with $\mathrm{H}_{2} \mathrm{O}(10 \times 20 \mathrm{~mL})$ and $\mathrm{EtOH}(3 \times 10 \mathrm{~mL})$ and dried in an oven at $80^{\circ} \mathrm{C}$.

Procedure for the preparation of creatine modified bentonite Pd NPs (bento-crt@Pd)

Bento-crt $(1 \mathrm{~g})$ was sonicated in THF $(10 \mathrm{~mL})$, and sonically assistance $\mathrm{PdCl}_{2}(0.1 \mathrm{mmol}, 18 \mathrm{mg})$ in $\mathrm{H}_{2} \mathrm{O}(5 \mathrm{~mL})$ was added. Then, $\mathrm{NaBH}_{4}(1 \mathrm{mmol}$ $37 \mathrm{mg}$ ) in $\mathrm{H}_{2} \mathrm{O}(1 \mathrm{~mL})$ was added slowly, and the resulting mixture was stirred for $24 \mathrm{~h}$ at room temperature. Then, the reaction mixture was subjected to centrifugation and resulting solid was washed with $\mathrm{H}_{2} \mathrm{O}(2 \times 10$ $\mathrm{mL}$ ) and ethyl acetate $(3 \times 5 \mathrm{~mL})$ to remove unreacted materials and dried in an oven at $70^{\circ} \mathrm{C}$.

\section{Procedure for the preparation of Bentonite supported Pd}

Sonically assisted $\mathrm{PdCl}_{2}(0.1 \mathrm{mmol}, 18 \mathrm{mg})$ in $\mathrm{H}_{2} \mathrm{O}(5 \mathrm{~mL})$ was added to a stirring flask containing bentonite $(1 \mathrm{~g})$ and $\mathrm{THF}(10 \mathrm{~mL})$. Then, $\mathrm{NaBH}_{4}(1$ $\mathrm{mmol}, 37 \mathrm{mg}$ ) in $\mathrm{H}_{2} \mathrm{O}(1 \mathrm{~mL})$ was added slowly, and the resulting mixture was stirred for $24 \mathrm{~h}$ at room temperature. Afterward, the reaction mixture was subjected to centrifugation and resulting solid was washed with $\mathrm{H}_{2} \mathrm{O}$ $(10 \mathrm{~mL})$ and ethyl acetate $(3 \times 5 \mathrm{~mL})$ to remove by-products and unreacted materials and dried in an oven at $70^{\circ} \mathrm{C}$.

General procedure for the reduction of nitroaromatic using bentocrt@Pd

To a $5 \mathrm{~mL}$ flask containing bento-crt@Pd (7 mg containing $0.1 \mathrm{~mol} \% \mathrm{Pd})$, nitroarene $(0.5 \mathrm{mmol}), \mathrm{NaBH}_{4}(2 \mathrm{mmol}, 75 \mathrm{mg})$ and $1: 1$ mixture of $\mathrm{H}_{2} \mathrm{O}$ : 
$\mathrm{EtOH}(1.5 \mathrm{~mL})$ were added. The reaction mixture was stirred at room temperature for the appropriate reaction times, and the progress of the reactions was monitored by GC, TLC and or ${ }^{1} \mathrm{H}$ NMR. After completion of the reaction, the crude product was extracted with ethyl acetate $(3 \times 5 \mathrm{~mL})$ and further purified using column or plate chromatography.

\section{Acknowledgements}

The authors are grateful to Institute for Advanced Studies in Basic Sciences (IASBS) Research Council and Iran National Science Foundation (INSF-Grant number of 97021804) for support of this work. We also thankful to the Spanish Ministerio de Economía, Industria y Competitividad, AgenciaEstatal de Investigación (AEI) and Fondo Europeo de Desarrollo Regional (FEDER, EU) (projects CTQ2016-76782$\mathrm{P}$ and CTQ2016-81797-REDC), the Generalitat Valenciana (PROMETEOII/2014/017) and the University of Alicante for financial support.

Keywords: Amino acids $\cdot$ clays $\cdot$ heterogeneous catalysis $\cdot$ palladium $\cdot$ nitro reduction

[1] S. Nishimura, Handbook of heterogeneous catalytic hydrogenation for organic synthesis. Wiley New York etc, 2001.

[2] Bechamp, A., Ann. Chim. Phys. 1854, 42, 140.

[3] a) B. Zeynizadeh, Z. Shokri, M. Hasanpour Galehban, Appl. Organomet. Chem. 2019, e4771; b) M. Gholinejad, N. Dasvarz, M. Shojafar, J. M. Sansano, Inorganica Chim. Acta 2019, 495, 118965; c) J. Feng, S. Handa, F. Gallou, B. H.Lipshutz, Angew. Chem. 2016, 128, 9125-9129; d) I. Pogorelić, M. Filipan-Litvić, S. Merkaš, G. Ljubić, I. Cepanec, M. Litvić, J. Mol. Catal. A: Chem. 2007, 274, 202-207; e) K. Nomura, J. Mol. Catal. A: Chem. 1995, 95, 203-210; f) M. Miura, M. Shinohara, M. Nomura, J. Mol. Catal. 1988, 45, 151-153; g) R. Adams, F. Cohen, O. Rees, J. Am. Chem. Soc. 1927, 49, 1093-1099.

[4] a) Z. Li, D. Zhao, J. Luo, Inorg. Chem. Commun. 2019, 100, 1-5; b) H. Pang, F. Gallou, H. Sohn, J. Camacho-Bunquin, M. Delferro, B. H. Lipshutz, Green Chem. 2018, 20, 130-135; c) M. Gholinejad, F. Zareh, C. Nájera, Appl Organometal Chem. 2017, e3984; d) B. S. Kumar, A. J. Amali, K. Pitchumani, J. Mol. Catal. A: Chem. 2016, 423, 511-519; e) A. B. Dongil, L. Pastor-Pérez, J. L. G. Fierro, N. Escalona, A. SepúlvedaEscribano, Appl. Catal., A 2016, 513, 89-97; f) M. Shokouhimehr Catalysts 2015, 5, 534-560; g) H. K. Kadam, S. G. Tilve, RSC Adv. 2015, 5, 83391-83407; h) T. Jiang, S. Du, T. Jafari, W. Zhong, Y. Sun, W. Song, Z. Luo, W. A. Hines, S. L. Suib, Appl. Catal., A 2015, 502, 105-113; i) B. Karimi, F. Mansouri, H. Vali, ChemPlusChem 2015, 80, 1750-1759; j) A Kumar, K. Purkait, S. K. Dey, A. Sarkar, A. Mukherjee, RSC Adv. 2014 4, 35233-35237; k) P. Wang, H. Liu, J. Niu, R. Li, J. Ma, Catal. Sci. Technol. 2014, 4, 1333-1339; I) M. Baron, E. Metay, M. Lemaire, F. Popowycz, Green Chem. 2013, 15, 1006-1015; m) M. L. Kantam, R. Chakravarti, U. Pal, B. Sreedhar, S. Bhargava, Adv. Synth. Catal. 2008, 350, 822-827.

[5] C. E. Garrett, K. Prasad, Adv. Synth. Catal. 2004, 346, 889-900.
[6] a) A. Ghaderi, M. Gholinejad, H. Firouzabadi, Curr. Org. Chem. 2016, 20, 327-348; b) O. Ayodele, B. Hameed, J. Ind. Eng. Chem. 2013, 19, 966974; c) G. Nagendrappa, Appl. Clay Sci. 2011, 53, 106-138; d) A. Gil, S. Korili, M. Vicente, Catal. Rev. 2008, 50, 153-221; e) R. B. Achma, A. Ghorbel, A. Dafinov, F. Medina, Appl. Catal., A 2008, 349, 20-28.

[7] a) M. Nasrollahzadeh, S. M. Sajadi, M. Maham, I. Kohsari, Microporous and Mesoporous Mater. 2018, 271, 128-137; b) M. Moosavi, Iran. J. Public Health 2017, 46, 1176; c) D. D. Eisenhour, R. K. Brown, Elements. 2009, 5, 83-88; d) J. W. Hosterman, Bentonite and Fuller's earth resources of the United States, 1985.

[8] a) Y. Jiang, T. Huang, Y. Xu, X. Li, Z. Qin, H. Ji, Chem. Eng. Technol. 2018, 41, 175-181; b) M. Gholinejad, R. Bonyasi, C. Najera, F. Saadati, M. Bahrami, N. Dasvarz, ChemPlusChem 2018, 83, 431 - 438; c) L. Yuan, Pol. J. Environ. Stud. 2017, 26, 2355-2361; d) V. M. Abbasov, H. C. Ibrahimov, G. S. Mukhtarova, M. I. Rustamov, E. Abdullayev, Energy Fuels 2017, 31, 5840-5843; e) Y. Jiang, X. Li, Z. Qin, H. Ji, Chin. J , Chem. Eng. 2016, 24, 1195-1200; f) H. Gaffour, M. Mokhtari, Res. Chem. Intermed. 2016, 42, 6025-6038.

[9] a) D. Gangopadhyay, S. K. Singh, P. Sharma, H. Mishra, V. Unnikrishnan, B. Singh, R. K. Singh, Spectrochim. Acta, Part A 2016, 154, 200-206; b) J. Dulinska, Z. Setkowicz, K. Janeczko, C. Sandt, P. Dumas, L. Uram, K. Gzielo-Jurek, J. Chwiej, Anal. Bioanal. Chem. 2012, 402, 2267-2274.

[10] a) D. Huang, Z. L. Wu, W. Liu, N. Hu, H. Z. Li, Chem. Eng. Process. 2016, 104, 13-21; b) I. Pischel, T. Gastner, Creatine-its chemical synthesis, chemistry, and legal status, 2007; pp 291-307.

[11] a) H. Firouzabadi, N. Iranpoor, A. Ghaderi, M. Gholinejad, S. Rahimi, S. Jokar, RSC Adv. 2014, 4, 27674-27682; b) K. Datta, M. Eswaramoorthy, C. Rao, J. Mater. Chem. 2007, 17, 613-615.

[12] a) Z. Issaabadi, M. Nasrollahzadeh, S. M. Sajadi, J. Cleaner Prod. 2017 142, 3584-3591; b) G. Ding, W. Wang, T. Jiang, B. Han, Green Chem. 2013, 15, 3396-3403.

[13] M. Gholinejad, M. Afrasi, N. Nikfarjam, C. Nájera, Appl. Catal., A 2018, 563, 185-195.

[14] C. Nithya, S. B. Devi, S. Gopukumar, J. Mater. Sci. 2012, 47, 6784-6791.

[15] Y. Zhang, L. Chen, J.-J. Zhao, H.-B. Chen, M.-X. He, Y.-P. Ni, J.-Q. Zhai, X.-L. Wang, Y.-Z. Wang, Polym. Chem. 2014, 5, 1982-1991.

[16] Q. Liu, J. Li, Z. Zhou, J. Xie, J. Y. Lee, Sci. Rep. 2016, 6, 19593.

[17] a) V. Dalmoro, J. H. dos Santos, I. M. Baibich, I. S. Butler, E. Armelin, C. Alemán, D. S. Azambuja, Prog. Org. Coat. 2015, 80, 49-58; b) Y. Zhang X. He, J. Ouyang, H. Yang, Sci. Rep. 2013, 3, 2948.

[18] A. Kumar, S. Samanta, S. Latha, A. Debnath, A. Singh, K. Muthe, H. C Barshilia, RSC Adv. 2017, 7, 4135-4143.

[19] S. Yuan, J. Gu, Y. Zheng, W. Jiang, B. Liang, S. O. Pehkonen, J. Mater Chem. A 2015, 3, 4620-4636.

[20] a) T. Lu, R. Zhang, C. Hu, F. Chen, S. Duo, Q. Hu, Phys. Chem. Chem Phys. 2013, 15, 12963-12970; b) A. Lopez-Santiago, H. R. Grant, P. Gangopadhyay, R. Voorakaranam, R. A. Norwood, N. Peyghambarian, Opt. Mater. Express 2012, 2, 978-986.

[21] a) Y. Zhang, Z. Xie, Z. Wang, X. Feng, Y. Wang, A. Wu, Dalton Trans 2016, 45, 12653-12660; b) E. Mazzotta, S. Rella, A. Turco, C. Malitesta, RSC Adv. 2015, 5, 83164-83186.

[22] M. Gholinejad, M. Bahrami, C. Nájera, Mol. Catal. 2017, 433, 12-19.

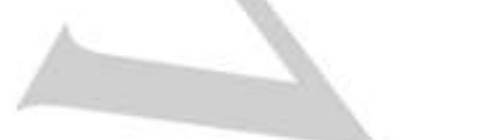




\section{WILEY-VCH}

\section{FULL PAPER}

\section{Entry for the Table of Contents}

Layout 1:

\section{FULL PAPER}

A new sustainable $P d$ catalyst comprising Pd NPs supported on creatine modified bentonite has been developed for the reduction of nitroarenes.

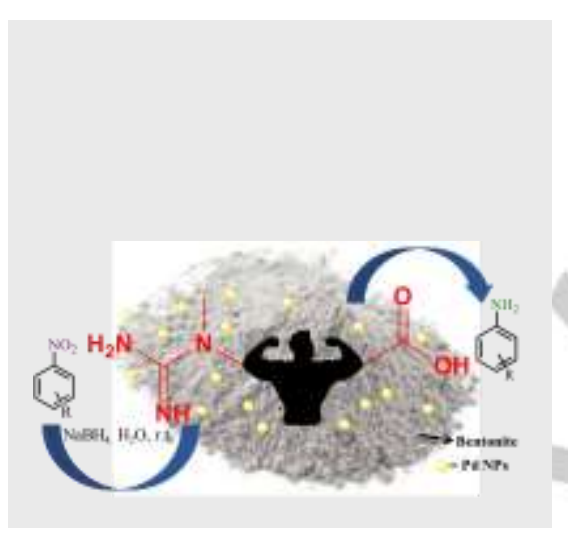

Mohammad Gholinejad, Zahra Rasouli, Carmen Nájera, and José M. Sansano

Page No. - Page No.

Palladium Nanoparticles on a Creatine-Modified Bentonite Support: An Efficient and Sustainable Catalyst for Nitroarene Reduction 